\title{
EDITORIAIS
}

\section{HEPATITES VIRAIS: UM DESAFIO NACIONAL}

As hepatites virais constituem um complexo de doenças com pelo menos cinco agentes, quais sejam as hepatites A e B, duas formas de hepatite não- $\mathrm{A} /$ não-B e as infecções pelo agente delta. Grandes segmentos de nossa população são infectados por estes agentes a cada ano, com um enorme impacto nos sistemas de saúde e na própria economia nacional. Informações confiáveis sobre a incidência e a prevalência das hepatites são de dificil obtenção pela alta incidência de infecções subclínicas, a falta de um sistema de notificação adequado e a não confirmação laboratorial das infecções, pelo alto custo dos reativos para diagnóstico laboratorial, em sua grande maioria ainda importados.

A hepatite $A$ apresenta uma epidemiologia bem definida, com infecções subclínicas no início de vida e manifestações clínicas em idades mais avançadas. $O$ virus $\mathbf{A}$ da hepatite é hoje classificado no grupo das enteroviroses, o que bem earacteriza sua capacidade de transmissão rápida em condições de baixa higiene e através da água e alimentos contaminados. A vacinação parece ser a única medida aplicável ao seu controle, e neste campo esforços vêm sendo realizados no sentido de se obter uma vacina, ainda sem resultados definitivos.

A hepatite B constitui problema particular, no qual parcela ponderável das infecções, especialmente as que ocorrem no início da vida, evoluem para infeç̧ão crônica e as seqüelas, como cirrose, hepatite crônica ativa e o carcinoma hepatocelular. Calcula-se que no mundo pelo menos 200 milhões de pessoas são carreadores persistentes do virus da hepatite $B$ e que $80 \%$ das neoplasias primárias hepatocelulares sejam causadas por este virus.

No Brasil, está demonstrado que, do sul para o norte do pais, eleva-se a taxa de portadores do virus a qual vem a alcançar em áreas da região amazônica valores em torno de $10 \%$, o que caracteriza a gravidade do problema. Dados mais recentes têm identificado em outros pontos do país áreas de alta incidência do virus e pesquisas mais amplas são essenciais nesta fase de equacionamento do problema.

\section{VIRAL HEPATITIS: A NATIONAL PROBLEM}

Viral hepatitis is a complex entity caused by at least five agents namely hepatitis viruses $A$ and $B$, two forms of hepatitis non $A /$ non $B$ and agent delta. Large numbers of our population are infected yearly by these viruses causing an enormous impact on our health system and the national economy. Realiable information on the incidence and prevalence of hepatitis is difficult to obtain due to the high incidence of subclinical infections and the absence of an adequate system of notifications. Laboratory confirmation is frequently lacking due to the high cost of diagnostic reagents which usually have to be imported.

Hepatitis A has a well defined epidemiology, with subclinical infections in early life and clinical manifestations in older people. Today the hepatitis virus is classified among the enteroviruses which are characterized by their capacity for rapid transmission in poor hygiene conditions by contaminated food or water. A vaccine would seem to be the only viable control measure and much research effort is currently directed toward this aim although a definitive solution is not yet forthcoming.

Hepatitis B constitutes a particularly serious problem, especially when infection occurs in early life, since often chronic disease ensues with serious sequelae such as cirrhosis, chronic active hepatitis and hepatocellular carcinoma. It is calculated that at least 200 million people in the world are persistent carriers of virus B and $80 \%$ of primary hepatocellular neoplasms are caused by this virus.

It has been shown that in Brazil there is a high rate of carriers from the south to the north of the country reaching $10 \%$ in some Amazonian areas; an illustration of a serious problem. 
O controle das infecções iatrogênicas está a exigir a produção de reagentes nacionais em custo $e$ qualidade que os tornem acessiveis a todo o país.

Para esta virose dispõe-se de vacinas de aceitáveis niveis de segurança e eficácia apesar de preparadas a partir de plasma humano contaminado com o vírus; o preço elevado do produto importado constitui o grande obstáculo para sua aplicação em escala ampla. Por outro lado, a atual tecnologia de preparo da vacina é perfeitamente acessivel ao nosso estágio de desenvolvimento, o que indica que nos cabe assumir este preparo, para se chegar ao controle da virose, em especial em áreas de maior incidência, como na região amazônica. Assinale-se que exatamente nesta região está sendo observada clínica e laboratorialmente a presença de uma forma grave de hepatite, causada pela superinfecção de carreadores crônicos de hepatite B, por um novo agente, denominado delta, descrito originalmente na Itália. No episódio estudado inicialmente, em populações indigenas da Venezuela, observou-se uma taxa de letalidade de $20 \%$, com a progressão de $60 \%$ dos sobreviventes à forma crônica. A possibilidade do envolvimento do agente delta na etiologia da febre negra de Lábrea, a ser melhor definida proximamente, pode se constituir em notável contribuição de nossa pesquisa médica no campo das hepatites e da medicina tropical. Como o agente delta somente é capaz de replicar em células infectadas concomitantemente ou previamente com o virus da hepatite $B$, constitui a vacinação contra esta virose medida eficaz de controle igualmente das infecções pelo agente delta, o que reforça a necessidade de se avaliar a produção deste produto no país.

As chamadas hepatites não- $\mathrm{A} /$ não- $\mathrm{B}$, apresentam-se sob duas formas, uma delas epidêmica, transmitida por via oral, associada à alta mortalidade (cerca de $18 \%$ ) em mulheres grávidas e causada por um agente com características próximas ao da hepatite $\mathrm{A}$, pelo menos morfologicamente. $\mathrm{Na}$ forma endêmica devem estar envolvidos dois agentes antigenicamente diferentes, faltando, porém, melhor definição a ser obtida através de pesquisas no momento em franco desenvolvimento. No nosso pais dispomos apenas de dados fragmentários sobre as hepatites não- $\mathrm{A} /$ não-B $\mathrm{e}$ certamente muito se poderia contribuir nesta área através do estabelecimento de estudos clínicos, laboratoriais e epidemiológicos, adequadamente financiados.

Em resumo, pode-se afirmar em relação às hepatites virais que as mesmas devem ser colocadas no mesmo nivel das grandes endemias nacionais; programas especificos de controle das hepatites virais
To control iatrogenic infections it is necessary to produce reagents of satisfactory quality and price at a national level so that they can be available throughout the country.

For this virus vaccines of acceptable efficacy and safety are available although they are prepared from human plasma contamined with the virus. The high price of the product is the obstacle to its use on a large scale. On the other hand the technology necessary to prepare the vaccine is perfectly accessible to our developmental resources. We have the capacity to make this vaccine to control the virus especially in areas of high incidence such as the Amazon region. It is exactly in this region that clinical and laboratory observations confirm the presence of a severe form of hepatitis caused by superinfection of hepatitis B carriers with a new agent delta described originally in Italy. In an epidemic studied in an indigenous Venezuelan population a $20 \%$ mortality was observed and $60 \%$ of the survivors developed chronic hepatitis. The possibility that delta agent is involved in the etiology of the black fever of Labrea will be clarified shortly. This may be a significant contribution to our knowledge of hepatitis in tropical medicine. Since the delta agent can only multiply in cells infected concomitantly or previously with the hepatitis $B$ virus, a vaccine against the latter will serve to control infections by the delta agent. This fact emphasizes the necessity to produce this vaccine in Brazil.

The so called hepatitis non $\mathrm{A} /$ non $\mathrm{B}$ has two forms. One epidemic, transmitted orally, associated with a high mortality (about $18 \%$ ) in pregnant women and caused by an agent with characteristics (at least morphological) close to hepatitis A. In the endemic form two antigenically different agents are envolved. Better definition of this situation is a subject of current research. In our country we have only fragmentary data regarding the occurrence of non $A /$ non $B$ hepatitis. Certainly adequately financed clinical, laboratory and epidemiological studies can make a contribution here.

In summary it can be stated that viral hepatitis should be considered at the same level as other great endemic diseases. Specific programmes for the control of viral hepatitis should be established at a central and 
da fronteira entre o Brasil e a Venezuela. Seu número é estimado em 18000 indivíduos, dos quais a terça parte, pelo menos, vive no Brasil, formando mais de 200 aldeias, esparsamente distribuidas pelo norte do Estado do Amazonas e parte ocidental do Território de Roraima. Vários fatores, como a prática do infanticidio e as constantes lutas entre tribos inimigas, têm contribuido para manter uma certa estabilidade na população. A maior concentraçao de aldeias, em território brasileiro, ocorre nas imediações das serras dos Surucucus e Couto de Magalhães.

O fato de a oncocercose - doença alóctone no continente americano - ter surgido em um grupo primitivo indigena, sem maiores contatos com estranhos, desperta logo, é óbvio, interesse quanto à sua origem, para avaliar-se o risco que a mesma poderá representar, no futuro, à saúde pública do Pais. Assim, deixando de lado o caminho, ainda misterioso, por ela seguido até instalar-se nos Yanomami, caso seja antiga, de tempos remotos, é improvável que venha a se estender muito além dos limites atuais, pois só dentro deles certamente existiriam as condições necessárias à sua persistência. Ao contrário, se introduzida recentemente, sua expansão talvez não esteja ainda encerrada, e novos focos terão condições de aparecer, mais cedo ou mais tarde, em lugares próximos ou distantes. No presente, o avanço estaria contido pelo próprio isolamento do grupo indígena; a perda desse estado poderia conduzir, então, ao espalhamento da endemia.

Certos indicativos, a seguir relacionados, permitem-nos afirmar que a oncocercose foi introduzida no território Yanomami não há muito tempo, provavelmente a partir de focos mais antigos existentes na Venezuela e conhecidos desde 194912 :

1) algumas características da doença nos indigenas afetados, como baixa densidade de infecção (número de microfilárias por miligrama de pele) e ausência de lesões graves, quer cutâneas, quer oculares $^{2}$, ao lado da completa ignorância por parte do grupo sobre as alterações oncocercóticas, mesmo as mais evidentes, sugerem uma existência muito curta da endemia entre os Yanomami;

2) uma pesquisa, que incluiu o exame fisico dos indígenas, feita por Salzano e Neel15, poucos anos antes do descobrimento da oncocercose nos Yanomami, nada revelou que pudesse levantar a mínima suspeita de estar a doença presente no grupo;

3) a predominância das microfilárias de Onchocerca volvulus na parte inferior do corpo, entre os Yanomami parasitados, é uma caracteristica que também se verifica nas áreas endêmicas mais antigas mated at 18,000 members, of whom at least a third live in Brazil forming more than 200 settlements or malocas scattered in the north of the state of Amazonas and the western part of the territory of Roraima. Various factors, such as the practice of infanticide and the constant fights with enemy tribes, have contributed to maintain a certain stability among this population. The major concentration of malocas in Brazilian territory occur near the highlands of Surucucus and Couto de Magalhães.

The fact that onchocerciasis, a disease that is not autochthonous in the American continent, has appeared in a primitive indian group without contact with strangers arouses interest in its origin to evaluate the risk it may represent to the public health of the country in the future. Although the manner in which the infection became endemic in the Yanomami is unknown certainly conditions exist for its persistence. If it was recently introduced it could be still spreading and sooner or later will appear in other localities. At the moment the isolation of the indians restrict it but if this isolation is lost it could spread.

There are certain indications that onchocerciasis was introduced into Yanomami territory relatively recently from longstanding foci existing in Venezuela and known since 194912. These are as follows:

1) Certain characteristics of the infection in man. Low density of infection (number of microfilariae per milligram of skin) and absence of severe skin or eye lesions. Also complete ignorance on the part of the people regarding onchocerciasis and the alterations it produces.

2) An investigation, including a physical examination of the indians, reported by Salzano and Neel15 a few years before the discovery of onchocerciasis in the Yanomami which did not raise any suspicion the disease was present in the group.

3) A predominance of microfilariae of Onchocerca volvulus in the inferior body segment in parasitized Yanomami, a characteristic which occurs in the oldest endemic areas of Venezuela. In Mexico and 
da Venezuela; no México e na Guatemala, as microfilárias são mais abundantes na parte superior do corpo;

4) como não houve tráfico de escravos na região do extremo norte ocupada pelos Yanomami, é remota a possibilidade de a oncocercose ter sido levada até lá por africanos doentes introduzidos no Brasil, na época da escravidão.

De qualquer modo, recente ou mesmo antiga, a doença teve, sem dúvida, como obstáculo maior, a impedir-lhe a propagação, o isolamento em que viviam os indigenas. A rudeza do terreno nativo, com selva densa, elevações constantes e rios fortemente encachoeirados, somada à conhecida belicosidade Yanomami, asseguraram-lhes, durante muito tempo, a inviolabilidade do território, limitando a endemia.

$O$ encontro, no entanto, de valiosas jazidas minerais em suas terras, e a demanda, sempre crescente, de novas áreas para a agricultura na região têm gerado acirradas disputas entre grupos pró e contra a preservação desse isolamento. A controvérsia de maior destaque diz respeito ao projeto de abertura dos garimpos de ouro e cassiterita, na serra dos Surucucus, a empresas mineradoras, projetọ cuja aprovação traria enorme beneficio econômico ao Território de Roraima. Por outro lado, a conseqüência imediata seria a penetração, na selva dos Surucucus - onde maior é a concentração Yanomami e onde maior é também a prevalência da oncocercose - de um contingente enorme de alienigenas, cujos membros, na maior parte, cedo, fatalmente, acabariam infectados.

O que sobreviria não se pode prever, mas o risco de a endemia expandir-se deve aumentar: os garimpeiros são nômades por natureza e a questão da existência de possiveis vetores de $O$. volvulus, em outros locais da Amazônia, permanece ainda em aberto 131617 . Embora a espécie de simulídeo mais eficaz na transmissão esteja, ao que indica, restrita às porções mais altas e longinquas do território Yanomami, um bom vetor em potencial vem de ser descoberto nos arredores da própria cidade de Boa Vista.

Ainda que as perspectivas sobre o futuro do foco Yanomami de oncocercose sejam bastante reservadas, pouco, até agora, tem sido feito para determinar-se as verdadeiras dimensões da atual área endêmica, a gravidade da infecção nos pontos mais afetados e, em especial, a possibilidade de focos secundários virem a se constituir, acompanhando o desenvolvimento econômico do Território de Roraima. Em parte, o atraso nas investigaçōes resultou das dificuldades inerentes à
Guatemala the microfilariae are commoner in the superior segment.

4) Since there was no slave traffic in the extreme north occupied by the Yanomami it is unlikely the onchocerciasis was introduced from Africa.

Whether the disease introduction is old or recent certainly the isolation of the indians impedes its spread. The rough country, with dense forest, mountains and rivers with waterfalls and the aggressive nature of the Yanomami have rendered their territory relatively inviolate, limiting the disease.

The discovery of valuable mineral deposits in their land and the increasing demand for new agricultural areas has generated disputes among groups which are for or against preserving the isolation of the Yanomami. A major controversy has occurred with respect to the mining of gold and tin in the Surucucus range; a project which would bring enormous economic benefit to the territory of Roraima. This would imply a relative invasion by mining personnel of the onchocerciasis endemic area. These people are nomadic by nature of their employment and they could carry infection to other areas in Amazonia where possible vectors of $O$. volvulus exist 131617 . Although the most efficient simulid vector is restricted to the highest part of Yanomami territory, a good potential vector has been discovered in the suburbs of the city of Boa Vista.

Although the future of the Yanomami focus of onchocerciasis is unclear still little has been done to define the actual endemic area, detect the foci of major endemicity and especially the appearance of secondary foci as a result of the development of Roraima territory. This is due not only to the difficulties of working in the region but also to the little importance given to a problem which is limited to a remote corner of the country.

Considering that at the moment it is impractical to control the disease in Amazonas the effort should be directed to avoiding dissemination. It is an arduous task as shown by the little work already done among the Yanomami with onchocerciasis. The following 
região, mas também, em parte, da pouca importância atribuida ao problema, que é pequeno, limitado e em sítio remoto do Pais.

Levando em conta que, no momento, é impraticável o controle da doença no meio amazônico, todos os esforços deverăo ser dirigidos no sentido de evitarlhe a disseminação. A tarefa é árdua, como o atestam as poucas tentativas, já feitas, de combate à oncocercose nos Yanomami, as quais têm sempre esbarrado nos seguintes obstáculos: distâncias imensas e transporte difícil na área, dispersão das aldeias e pequeno número de habitantes em cada uma, comunidades numerosas ainda desconhecidas ou inacessíveis, insuficiência de meios para um tratamento em massa (drogas não isentas de perigo e falta de recursos para uma supervisão médica adequada), natural aversão dos indígenas a aplicaçōes intravenosas (como requerido pelo único tratamento realmente eficaz disponivel) e, mais, a grande largura e vazão dos rios amazônicos, que tornam impossivel o controle dos vetores através do emprego de larvicidas. Mesmo assim, não se pode aguardar passivamente o progresso, ainda que incerto, da endemia; medidas devem ser adotadas para conhecê-la melhor e então, se possivel, embargar-lhe os passos.

\section{REFERÊNCIAS BIBLIOGRÁFICAS}

1. Bearzoti P, Lane E, Menezes Jr J. Relato de um caso de oncocercose adquirida no Brasil. Revista Paulista de Medicina 70: 102, 1967.

2. Belfort Jr R, Moraes MAP. Oncocercose ocular no Brasil. Revista da Associação Médica Brasileira 25: 123-127, 1979.

3. Moraes MAP, Dias LB. Oncocercose no Estado do Amazonas. Revista do Instituto de Medicina Tropical de São Paulo 14: 330-333, 1972.

4. Moraes MAP, Fraiha H, Chaves GM. Oncocercose no Brasil. Boletin de la Oficina Sanitaria Panamericana 76: 48-53, 1974. Também publicado em Bulletin of the Pan American Health Organization 7: 51-56, 1973.

5. Moraes MAP, Chaves GM. Um caso de oncocercose no Território de Roraima, Brasil. Revista do Instituto de Medicina Tropical de Săo Paulo 16: 110-113, 1974.

6. Moraes MAP, Chaves GM. Oncocercose no Brasil; novos achados entre indios Ianomamas. Boletin de la Oficina Sanitaria Panamericana 77: 1-5, 1974. Também publicado em Bulletin of the Pan American Health Organization 8: 95-99, 1974. obstacles have to be overcome: immense distances and difficult transportation, scattered settlement with small numbers of inhabitants, numerous communities still unknown or inaccessible, insufficient means for mass treatment (drugs with dangerous side effects and lack of medical supervision), non cooperation on the part of the indians particularly to intravenous injections (the only really effective treatment available) and also the width and volume of the Amazonian rivers which make it impossible to control the vectors by using larvicides. However one cannot wait passively for the disease to spread, and some measures will have to be adopted.

7. Moraes MAP. Onchocerciasis in Brazil. In: Proceedings of an International Symposium on Research and Control of Onchocerciasis in the Western Hemisphere. OPS. Publicação Científica 298. Washington, DC, pp. 122$128,1974$.

8. Moraes MAP, Calheiros LB, Porto MAS, Neves RNA, Shelley AJ. Novas observações sobre o foco de oncocercose da área do rio Toototobi, Estado do Amazonas, Brasil. Boletin de la Oficina Sanitaria Panamericana 84: 510-519, 1978.

9. Moraes MAP, Porto MAS, Calheiros LB, Shelley AJ. Novas observações sobre o foco de oncocercose da área do rio Auaris, Território de Roraima, Brasil. Boletin de la Oficina Sanitaria Panamericana 86: 509-516, 1979.

10. Moraes MAP, Porto MAS, Calheiros LB, Shelley AJ. Oncocercose no Território de Roraima; resultados das investigações feitas nos rios Mucajai e Catrimâni, em janeiro de 1977. Boletim Epidemiológico da FSESP 9: 119,121 e $124,1977$.

11. Moraes MAP, Shelley AJ, Calheiros LB, Porto MAS. Estado atual do conhecimento sobre os focos brasileiros de oncocercose. Anais Brasileiros de Dermatologia 54: 73-85, 1979.

12. Potenza L, Febres Cordero R, Anduze PJ. Nuevo foco endemico de oncocercosis humana en el mundo: Venezuela. Boletin Medico de Caracas 1: 263-285, 1949.

13. Rassi BE, Lacerda N, Guimarães JA, Vulcano MA, Ramirez Perez J, Ramirez A. Preliminary report on a new vector of onchocerciasis in the Americas, Simulium amazonicum (Goeldi, Lutz, 1910 e 1917). Bulletin of the Pan American Health Organization 9: 10-12, 1975.

14. Rassi BE, Lacerda N, Guimarães JA. Estudio de una zona de oncocercosis en Brasil; encuesta realizada en residentes locales. Boletin de la Oficina Sanitaria Panamericana 80: 288-301, 1976. Também publicado em Bulletin of the Pan American Health Organization 10: $33-45,1976$. 
Editorial. O foco brasileiro de oncocercose. Mário A. P. Moraes. Revista da Sociedade Brasileira de Medicina Tropical 18: 71-75, Abr-Jun, 1985

15. Salzano FM, Neel JV. New data on the vision of South American Indians. Bulletin of the Pan American Health Organization 10: 1-8, 1976. Também publicado em Boletin de la Oficina Sanitaria Panamericana 81: 387393, 1976.

16. Shelley AJ, Pinger RR, Moraes MAP, Charlwood JD, Hayes J. Vectors of Onchocerca volvulus at the river
Toototobi, Brazil. Journal of Helminthology 53: 41-43, 1979.

17. Shelley AJ, Pinger RR, Moraes MAP. The taxonomy, biology and medical importance of Simulium amazonicum Goeldi (Diptera: Simuliidae), with a review of related species. Bulletin of the British Museum of Natural History (Entomology) 44: 1-29, 1982.

Mário A. P. Moraes

Universidade de Brasilia

Membro do Comitê de Peritos da O. M. S.

para Filarioses. 